Ambiente \& Água - An Interdisciplinary Journal of Applied Science
ISSN 1980-993X - doi:10.4136/1980-993X
www.ambi-agua.net
E-mail: ambi.agua@gmail.com

\title{
Biomass reduction of Salvinia molesta exposed to copper sulfate pentahydrate $\left(\mathrm{CuSO}_{4} .5 \mathrm{H}_{2} \mathrm{O}\right)$
}

\author{
doi: 10.4136/ambi-agua.1633
}

Received: 13 Apr. 2015; Accepted: 29 May 2015

\author{
João Pedro Alves de Azevedo Barros ${ }^{1}$; Matheus Nicolino Peixoto Henares ${ }^{2 *}$ \\ Centro Universitário da Fundação Educacional de Barretos (UNIFEB), Barretos, SP, Brasil \\ ${ }^{1}$ Departamento de Engenharia Química \\ ${ }^{2}$ Departamento de Engenharia Ambiental \\ *Corresponding author: e-mail: henaresmnp@gmail.com, \\ joaopedro345@hotmail.com
}

\begin{abstract}
Copper in the aquatic ecosystem may remain adsorbed or be incorporated into the biomass and undergo biomagnification causing unwanted effects to aquatic macrophyte communities. This study evaluated the biomass reduction of Salvinia molesta (Mitchell) exposed to copper sulphate pentahydrate $\left(\mathrm{CuSO}_{4} .5 \mathrm{H}_{2} \mathrm{O}\right)$ under laboratory conditions. Approximately $20.5 \mathrm{~g}$ of fresh mass (FM) of S. molesta $(0.74 \mathrm{~g}$ dry matter, DM) were placed in glass tanks with different concentrations $(\mathrm{n}=3)$ of $\mathrm{CuSO}_{4} .5 \mathrm{H}_{2} \mathrm{O}$ as follows: $0.0 ; 2.0 ; 4.0$; 6.0 ; and $8.0 \mathrm{mg} \mathrm{L}^{-1}$ for 28 days. The dry mass was determined after each seven-day interval over 28 days and submitted to repeated ANOVA measures, followed by a Tukey test $(P<0,05)$. The results show that macrophyte increased until the seventh day of exposure in all treatments. After this period, the biomass of $S$. molesta decreased; but there was no significant difference between treatments with copper, except for the $8.0 \mathrm{mg} \mathrm{L}^{-1}$ treatment. The copper treatments decreased the $S$. molesta biomass an average of $43.2 \%(0.50 \mathrm{~g} \mathrm{DM})$ after 28 days. At the end of the experiment, copper absorption in the treatments with 6.0 and $8.0 \mathrm{mg} \mathrm{L}^{-1}$ was on average $77.9 \%$ higher than in the treatments with 2 and $4 \mathrm{mg} \mathrm{L}^{-1}$. The treatments with 6.0 and $8.0 \mathrm{mg} \mathrm{L}^{-1}$ reached their maximum bioaccumulation capacity after 14 days. The results show that contamination of the aquatic environment at concentrations above $2 \mathrm{mg} \mathrm{L}^{-1} \mathrm{Cu}^{2+}$ can reduce the $S$. molesta biomass by approximately $43 \%$.
\end{abstract}

Keywords: aquatic macrophytes, heavy metal, phytoremediation.

\section{Redução da biomassa de Salvinia molesta exposta ao sulfato de cobre pentahidratado $\left(\mathrm{CuSO}_{4} .5 \mathrm{H}_{2} \mathrm{O}\right)$}

\section{RESUMO}

No ecossistema aquático, o cobre pode permanecer adsorvido ou ser incorporado à biomassa e sofrer biomagnificação ocasionando efeitos indesejados às macrófitas aquáticas. Este trabalho avaliou a redução da biomassa da Salvinia molesta (Mitchell) exposta ao sulfato de cobre pentahidratado $\left(\mathrm{CuSO}_{4} .5 \mathrm{H}_{2} \mathrm{O}\right)$, em condições de laboratório. Aproximadamente 20,5 g de massa fresca (MF) de S. molesta $(0,74 \mathrm{~g}$ de massa seca, MS) foram dispostas em aquários de vidro e submetidas $(\mathrm{n}=3)$ às concentrações de 0,$0 ; 2,0 ; 4,0 ; 6,0 ;$ e $8,0 \mathrm{mg} \mathrm{L}^{-1}$ por 
28 dias. A massa seca foi determinada a cada sete dias durante 28 dias e os dados submetidos à ANOVA de medidas repetidas, seguida do teste de Tukey $(P<0,05)$. Em todos os tratamentos $S$. molesta cresceu até o sétimo dia de exposição. Após esse período houve redução da biomassa de $S$. molesta, porém não ocorreu diferença significativa entre os tratamentos com cobre, exceto para o tratamento com $8.0 \mathrm{mg} \mathrm{L}^{-1}$. A redução média da biomassa de $S$. molesta nos tratamentos com cobre foi $43,2 \%(0,50 \mathrm{~g}$ MS) aos 28 dias. Ao final do experimento a absorção do cobre nos tratamentos com 6,0 e $8,0 \mathrm{mg} \mathrm{L}^{-1}$ foi em média $77,9 \%$ maior em comparação à absorção nos tratamentos com 2 e $4 \mathrm{mg} \mathrm{L}^{-1}$. Os tratamentos com 6,0 e $8,0 \mathrm{mg} \mathrm{L}^{-1}$ atingiram sua capacidade máxima de bioacumulação aos 14 dias. Os resultados mostram que contaminação de ambientes aquáticos com concentrações acima de $2 \mathrm{mg}$ de $\mathrm{Cu}^{2+} \mathrm{L}^{-1}$ pode ocasionar redução de aproximadamente $43 \%$ da biomassa de S. molesta.

Palavras-chave: fitorremediação, macrófitas aquáticas, metal pesado.

\section{INTRODUCTION}

Human activities cause multiple environmental impacts on aquatic environments. Among these activities, the incorrect use of fertilizers and increasing industrial activities have led to increasing contamination of soil and water bodies by metal ions (Moyo and Phiri, 2002; Espinoza-Quiñones et al., 2005; Penning et al., 2008).

Copper sulfate $\left(\mathrm{CuSO}_{4}\right)$ can contaminate aquatic ecosystems indirectly during the spraying of crops due to entrainment caused by rain and, naturally, by soil erosion. The copper ion also reaches aquatic environments directly when industrial effluents are released into water bodies and when copper sulfate is used to control algae in reservoirs and irrigation equipment (Who, 1998; Boyd, 2015). In Brazil, the use of copper sulphate pentahydrate $\left(\mathrm{CuSO}_{4} .5 \mathrm{H}_{2} \mathrm{O}\right)$ is not allowed; but it is widely used in other countries to control parasitoids in aquaculture (e.g. Ichthyophtirius mutifiliis), diseases of bacterial and fungal origin (Cardeilhac and Whitaker, 1988) and algae blooms, as well (Boyd and Massaut, 1999). In Brazil, the maximum value of copper concentration released in the receiving water bodies is $1.0 \mathrm{mg} \mathrm{L}^{-1}$ (Conama, 2011); however, continuous use on crops and in industrial activities may result in the accumulation of ions in aquatic ecosystems.

Copper is essential for certain cellular activities at low concentrations, but it can be toxic, causing mortality or sub-lethal stress in high concentrations (Mazon et al., 2000; Pourahmad and O' Brien, 2000). The presence of copper in the environment poses a toxicity threat to animals and plants (McBride et al., 1997). In aquatic ecosystems copper can be adsorbed to the sediment by ion complexation reactions and influence the bioavailability, transport and migration of metallic cations (Bezerra et al., 2009). As a result of its conservative characteristics, copper may result in bioconcentration and biomagnification in the food chain (Amarante et al., 2010; Marengoni et al., 2013).

Aquatic macrophytes play a key role in nutrient cycling and primary production of aquatic ecosystems, because they promote the exchange of chemical elements of the sediment to the water column and are an important food source for aquatic and terrestrial animals (food web), organic matter and debris (detritivores web), in addition to providing substrate, shelter and refuge for fish, zooplankton and macro-invertebrates (Camargo et al., 2003; Thomaz and Cunha, 2010; Mormul et al., 2010; Batista-Silva et al., 2012; Súarez et al., 2013).

Salvinia molesta (Mitchell) is a small, floating aquatic macrophyte of the Salvinaceae family, widely distributed in Brazil. The Salvinia genus is native to the Neotropics, extending from Mexico and the Galapagos Islands through Central America and Caribbean and most of South America (Sculthorpe, 1967). This macrophyte presents high growth rates, high rates of reproduction and the ability to accumulate nutrients (McFarland et al., 2004; Cary and 
Weerts, 1984). The sensitivity to different substances allows the use of S. molesta as a biological indicator of contaminated environments (Suñe et al., 2007) while its high growth rate favors its use as phytoremediation agent. In addition to the ability to absorb nutrients, Kumar et al. (2008) and Ladislas et al. (2012) reported that some species of macrophytes have great potential for removing heavy metals from water and sediments. Although the metal removal capacity is a desirable feature in macrophytes used in phytoremediation of contaminated aquatic environments, it is important to know the morphological and physiological damage caused by heavy metal accumulation on macrophyte tissues (Milan et al., 2006).

The accumulation of metals can reduce plant biomass and, consequently, habitat heterogeneity and primary production in aquatic environments. Proença et al. (2012) demonstrated that the aquatic macrophytes Lemna minor were able to grow in low copper concentrations $\left(0.01,0.1\right.$ and $\left.1.0 \mathrm{mg} \mathrm{L}^{-1}\right)$ (i.e., the stimulatory effect), but the biomass was reduced when exposed to a concentration of $10 \mathrm{mg} \mathrm{L}^{-1}$ (inhibitory effect). Cruz et al. (2009) used Pistia stratiotes L. (Araceae) to treat mining effluents containing $\mathrm{Mn}$ and $\mathrm{Zn}$ and reported that the accumulation of heavy metals in plant tissue may cause phytotoxicity and reduce plant biomass.

Floating aquatic macrophytes with large biomass, such as Eichhornia crassipes and Pistia stratiotes are often used for phytoremediation because they are more resistant to the adverse conditions of the contaminated water (Mondardo et al., 2006; Cruz et al., 2009). In an experiment using E. crassipes for 21 days, Mokhtar et al. (2011) reported the removal of 97.3, 95.6 and $61.6 \%$ of the copper present in solution with $1.5,2.5$ and $5.5 \mathrm{mg} \mathrm{L}^{-1}$, respectively.

The effects of copper on floating macrophyte with small biomass such as Salvinia molesta (Mitchell) are poorly understood. The wide geographic distribution of S. molesta in Brazil, even in environments with low nutrient concentrations (Rubim and Camargo, 2001), and the fact that $S$. molesta may be subjected to possible biomass reduction resulting from contamination by copper ions $\left(\mathrm{Cu}^{2+}\right)$ in aquatic environments, led us to evaluate the effects of copper sulfate pentahydrate on S. molesta biomass.

\section{MATERIALS AND METHODS}

An experiment was conducted to evaluate how copper affects Salvinia molesta biomass. The plants were exposed (in triplicate) to five copper sulphate pentahydrate concentrations $\left(0.0,2.0,4.0,6.0\right.$ and $\left.8.0 \mathrm{mg} \mathrm{L}^{-1}\right)$ in 5.0 liter capacity tanks in laboratory conditions for 28 days.

The plants were selected by size and appearance, in good health and nutritional status. The tanks were filled with two liters of water and an average $20.5 \mathrm{~g}$ of fresh mass (FM) of $S$. molesta, corresponding to approximately $0.74 \mathrm{~g}$ dry matter (DM). The fresh weight was determined after removing excess water by keeping the plants in the shadow, inside sieves for 5 minutes and, after that, they were laid on paper to drain for 2 minutes. The initial dry matter was estimated by simple linear regression between fresh (FM) and dry matter. The regression between FM and DM yielded a correlation value of $R^{2}=0.997 \quad(n=15)$ and the obtained equation was $\mathrm{DM}=0.0313^{*}(\mathrm{FM})+0.1019$. The dry weight was determined after the plants were dried at $105^{\circ} \mathrm{C}$ for 24 hours, as recommended by Wetzel and Likens (1991).

The copper sulfate pentahydrate $\left(\mathrm{CuSO}_{4} .5 \mathrm{H}_{2} \mathrm{O}\right.$, Pro analisis $\left.{ }^{\circledR}\right)$ was $99.99 \%$ pure. The water added to the laboratory tanks came from the $S$. molesta maintenance tanks to reduce the impact of the transfer on the plants. Table 1 presents the water physical and chemical variables. 
Table 1. Mean $(\mathrm{n}=3)$ and standard deviation values of temperature (temp.), $\mathrm{pH}$, dissolved oxygen (DO), electrical conductivity, total Kjeldahl nitrogen (TKN) and total phosphorus (TP) of water in the tanks.

\begin{tabular}{lcccccc}
\hline $\begin{array}{c}\text { Physical and } \\
\text { chemical variables }\end{array}$ & Temp. $\left({ }^{\circ} \mathrm{C}\right)$ & $\mathrm{pH}$ & $\begin{array}{c}\mathrm{DO} \\
\left(\mathrm{mg} \mathrm{L}^{-1}\right)\end{array}$ & $\begin{array}{c}\text { Electrical Cond. } \\
\left(\mathrm{mS} \mathrm{cm}^{-1}\right)\end{array}$ & $\begin{array}{c}\mathrm{TKN} \\
\left(\mathrm{mg} \mathrm{L}^{-1}\right)\end{array}$ & $\begin{array}{c}\mathrm{TP} \\
\left(\mu \mathrm{g} \mathrm{L}^{-1}\right)\end{array}$ \\
\hline $\begin{array}{c}\text { Macrophytes tanks } \\
\text { collection }\end{array}$ & $27.1 \pm 0.6$ & $7.9 \pm 0.4$ & $6.0 \pm 0.6$ & $0.094 \pm 0.023$ & $0.50 \pm 0.12$ & $205.0 \pm 29.1$ \\
\hline
\end{tabular}

The experiment was conducted in 60 tanks under controlled conditions $\left(26.5 \pm 2.0^{\circ} \mathrm{C}\right.$ and photoperiod of 8 hours). Every seven days, 15 tanks were removed and all macrophyte biomass was used to determine fresh mass (FM, g), dry matter (DM, g) and copper content. Copper content in the biomass of macrophytes $\left(\mathrm{mg} \mathrm{g}^{-1}\right)$ was determined following the B-3120 method described in APHA (2005). The 15 tanks corresponded to five treatments $(0.0 ; 2.0$; 4.0; 6.0 and $8.0 \mathrm{mg} \mathrm{L}^{-1}$ ) and three repetitions.

The data regarding dry matter and copper content in the macrophytes biomass at 7, 14, 21 and 28 days were subjected to descriptive statistics. Subsequently, the dry weight data were submitted to the Kolmogorov-Smirnov' and Bartlett's test to verify the normality and homoscedasticity, respectively. If the assumptions were confirmed, the dry weight data were submitted to repeated ANOVA measures to verify the effects of copper $(0.0 ; 2.0 ; 4.0 ; 6.0$ and $\left.8.0 \mathrm{mg} \mathrm{L}^{-1}\right)$ on the $S$. molesta biomass. Significantly different means $(P<0.05)$ were then compared by the Tukey test.

\section{RESULTS AND DISCUSSION}

The repeated ANOVA measures pointed to significant effects of treatments (i.e. copper concentrations) and time (samplings days). Interactions among the effects of time and copper concentrations were also observed (Table 2). In the control treatment, S. molesta biomass was significantly higher than in the others. Salvinia molesta exposed to $8.0 \mathrm{mg} \mathrm{L}^{-1}$ had lower biomass; and no significant difference was observed among $2.0,4.0$ and $6.0 \mathrm{mg} \mathrm{L}^{-1}$ treatments (Table 2).

Table 2. Mean ( $\mathrm{n}=12)$ of Salvinia molesta biomass (g DM) in different copper concentrations with results from the repeated measures ANOVA upon the effects of treatment (Treat.), time and interaction (Treat. $\mathrm{x}$ time).

\begin{tabular}{|c|c|c|c|c|c|c|c|c|}
\hline \multirow{3}{*}{$\begin{array}{c}\text { Copper } \\
\text { concentration } \\
\left(\mathrm{mg} \mathrm{L}^{-1}\right)\end{array}$} & \multicolumn{5}{|c|}{ Treatments (Treat.) } & \multicolumn{3}{|c|}{ Anova $P$ value } \\
\hline & 0.0 & 2.0 & 4.0 & 6.0 & 8.0 & Treat. & Time & $\begin{array}{c}\text { Treat. } \mathrm{x} \\
\text { Time }\end{array}$ \\
\hline & $0.98 \mathrm{a}$ & $0.63 b$ & $0.64 \mathrm{~b}$ & $0.64 \mathrm{~b}$ & $0.58 \mathrm{c}$ & $<0.001$ & $<0.001$ & $<0.001$ \\
\hline
\end{tabular}

The biomass of macrophyte increased until the seventh day of exposure in all treatments. After this period $S$. molesta biomass reduced, although not significantly different $(P<0.05)$ between treatments, except compared to the control (Figure 1). In the control treatment, biomass increased an average $29.7 \%$ throughout the experiment. At the end of the experiment, S. molesta biomass (mean $0.50 \mathrm{~g} \mathrm{DM}$ ) reduced on average $43.2 \%$ in the treatments with copper, compared to $7^{\text {th }}$ day (mean $\left.0.88 \mathrm{~g} \mathrm{DM}\right)$. After 28 days, biomass $(0.50 \mathrm{~g} \mathrm{DM})$ reduced $45.1 \%$ for $2.0 \mathrm{mg} \mathrm{L}^{-1}$ copper concentration and, $44.4 \%$ (0.50 g DM), 40.2\% (0.52 g DM) and $41.7 \%$ (0.49 g DM) for 4.0, 6.0 and $8.0 \mathrm{mg} \mathrm{L}^{-1}$, respectively (Figure 1). This result suggests that the contamination of the aquatic environment with concentrations greater than $2.0 \mathrm{mg} \mathrm{L}^{-1}$ can cause heavy losses to the $S$. molesta biomass. Exposure of Lemna minor to the 
concentration of $10 \mathrm{mg} \mathrm{L}^{-1} \mathrm{Cu}^{2+}$ reduced the biomass macrophyte by $62.1 \%$ (Proença et al., 2012). Salvinia auriculata exposed to zinc $\left(\mathrm{ZnSO}_{4} .7 \mathrm{H}_{2} \mathrm{O}\right)$ concentrations of 7.5 and $10.0 \mathrm{mg}$ $\mathrm{L}^{-1}$ decreased by 25 and 38\%, respectively (Wolff et al., 2009).

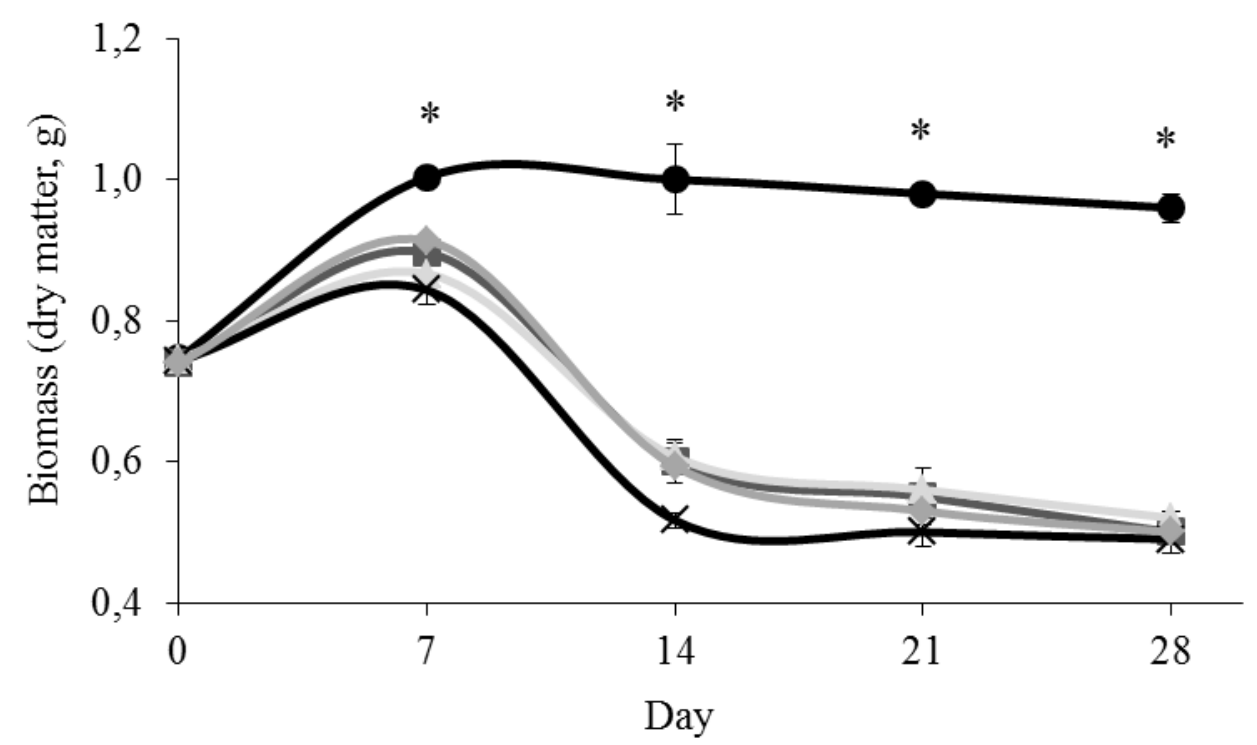

Figure 1. Means $(\mathrm{n}=3)$ and standard deviation of Salvinia molesta biomass in the $0.0(\bullet), 2.0(\bullet), 4.0(\bullet), 6.0(\mathbf{\Delta})$ and $8.0 \mathrm{mg} \mathrm{L}^{-1}(\mathrm{x})$; * denotes significantly different $(P<0.05)$ between treatments.

The biomass decreased with the copper treatment due to leaf necrosis after 14 days of trial and, especially, to early root senescence from the $7^{\text {th }}$ day. After this period, senescence and detachment from the plant roots could be observed. Several authors reported that heavy metals are not accumulated in the roots (Kumar et al., 2008; Mansouri et al., 2012; Rascio and Navari-Izzo, 2011); however, the floating aquatic macrophytes absorb most of the nutrients by the roots (Tundisi and Tundisi, 2008). This fact suggests that $S$. molesta biomass reduction begins in the root system caused by ion copper absorption. For example, in P. stratiotes mercury accumulation was about 4 times higher in roots than in the upper parts (Snow and Ghaly, 2008; Ayyasamy et al., 2009). So, although floating aquatic macrophyte with high biomass are more resistant to adverse environmental conditions, copper contamination of aquatic environments can reduce the biomass of species such as Eichhornia crassipes and Pistia stratiotes due to higher ion absorption caused by greater root area. The length of $S$. molesta roots (i.e., root-like structures that are actually modified leaves) ranges from about 2.4 to $10.5 \mathrm{~cm}$ (Room, 1983), whereas E. crassipes root length can reach $30 \mathrm{~cm}$ (Meerhoff et al., 2003).

At the end of the experiment, copper absorption in the treatments with $6.0\left(4.3 \mathrm{mg} \mathrm{g}^{-1}\right.$ $\mathrm{DM})$ and $8.0 \mathrm{mg} \mathrm{L}^{-1}\left(6.2 \mathrm{mg} \mathrm{g}^{-1} \mathrm{DM}\right)$ was on average $77.9 \%$ higher than in the treatments with $2.0\left(2.0 \mathrm{mg} \mathrm{g}^{-1} \mathrm{DM}\right)$ and $4.0 \mathrm{mg} \mathrm{L}^{-1}\left(3.9 \mathrm{mg} \mathrm{g}^{-1} \mathrm{DM}\right)$. Salvinia molesta exposed to copper concentrations of 6.0 and $8.0 \mathrm{mg} \mathrm{L}^{-1}$ absorbed more rapidly and reached maximum bioaccumulation capacity at 14 days, when the copper content in the macrophyte biomass reached 4.8 and $6.9 \mathrm{mg} \mathrm{Cu}^{2+} \mathrm{g}^{-1} \mathrm{DM}$, respectively (Figure 2). Probably this result is due to the higher initial availability of copper. Wolff et al. (2009) reported that the zinc content in $S$. auriculata biomass showed a positive relationship with the highest concentrations in the solution. In this study, a relationship between the initial concentration and the copper content in the macrophyte biomass was also observed. However, no positive correlation was observed between decreasing biomass and increasing concentration in the solution, because the 
reduction was similar in all concentrations, except for $8.0 \mathrm{mg} \mathrm{L}^{-1}$. In addition to the absorption process, the ion adsorption by macrophyte structures (e.g., root structures) favor the reduction of copper. In fact, Módenes et al. (2013) related that E. crassipes dry matter reduced about $50 \%$ of $\mathrm{Zn}, \mathrm{Cu}$ and $\mathrm{Cd}$ ions from aqueous solutions.

The copper content in the $S$. molesta dry matter also suggests that after 14 days copper starts to be transferred to the medium (i.e. solution), especially in the 6.0 and $8.0 \mathrm{mg} \mathrm{L}^{-1}$ treatments (Figure 2). This fact may be related to loss of copper absorption capacity resulting from ion saturation in the plant biomass. In the treatments with 2.0 and $4.0 \mathrm{mg} \mathrm{L}^{-1}$ copper content increased steadily in the macrophyte biomass, indicating that at these concentrations S. molesta did not reach maximum bioaccumulation capacity. Heavy metals such as cadmium, copper, lead, zinc and nickel can trigger toxic effects on organisms due to bioaccumulation and biomagnification in the food chain (Dembitsky and Rezanka, 2003; Ugya et al., 2015).

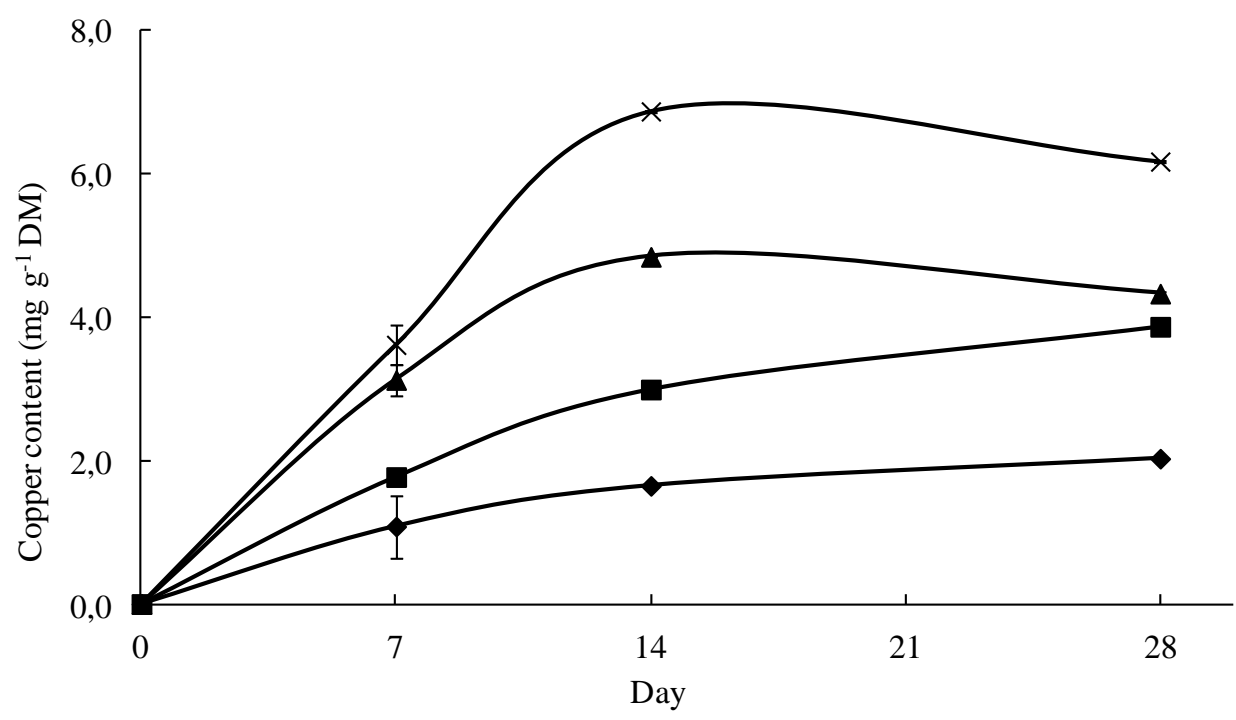

Figure 2. Copper content in Salvinia molesta biomass for the treatments with $2.0(\bullet)$, $4.0(\mathbf{\bullet}), 6.0(\boldsymbol{\Lambda})$ and $8.0 \mathrm{mg} \mathrm{L}^{-1}(\mathrm{x})$.

\section{CONCLUSION}

The exposure of Salvinia molesta to copper sulphate pentahydrate causes the macrophyte biomass to decrease; however, this decrease was similar in the $2.0 ; 4.0$ and $6.0 \mathrm{mg} \mathrm{L}^{-1}$ treatments, and slightly higher in the $8.0 \mathrm{mg} \mathrm{L}^{-1}$ treatment. Thus, no positive correlation was observed between copper concentration and biomass reduction. Nevertheless, at higher concentrations $\left(6.0\right.$ and $\left.8.0 \mathrm{mg} \mathrm{L}^{-1}\right)$ accumulation was also higher and possibly reached copper saturation due to rapid absorption of the ion. These results also suggest that contamination of the aquatic environment at concentrations of $2 \mathrm{mg} \mathrm{L}^{-1} \mathrm{Cu}^{2+}$ can reduce $S$. molesta biomass by approximately $43 \%$.

\section{ACKNOWLEDGEMENTS}

We are grateful to PIBIC/UNIFEB for providing fellowships to the first author. We would also like to thank the staff of Laboratory of Ecotoxicology and Effectiveness of Pesticides, UNIFEB for their technical support. 


\section{REFERENCES}

AMARANTE, C. B.; MULLER, R. C. S.; DANTAS, K. G. F.; ALVES, C. N.; MULLER, A. H.; PALHETA, D. C. Composição química e valor nutricional para grandes herbívoros das folhas e frutos de aninga (Montrichardia linifera, Araceae). Acta Amazonica, Manaus, v. 40, n. 4, p. 729-736, 2010. http://dx.doi.org/10.1590/S004459672010000400013

AMERICAN PUBLIC HEALTH ASSOCIATION - APHA. Standard methods for the examination of water and wastewater. $21^{\text {th }}$ ed. Washington, DC, 2005.

AYYASAMY, P. M.; RAJAKUMAR, S.; SATHISHKUMAR, M.; SWAMINATHAN, K.; SHANTHI, K.; LAKSHMANAPERUMALSAMY, P. et al. Nitrate removal from synthetic medium and groundwater with aquatic macrophytes. Desalination, Amsterdam, v. 242, p. 286-296, 2009. http://dx.doi.org/10.1016/j.desal.2008.05.008

BATISTA-SILVA, V. F.; BONETO, D. D.; BAILLY, D.; ABELHA, M. C. F.; KASHIWAQUI, E. A. L. Invertebrates associated to Eichhornia azurea Kunth in lagoon of the Upper Paraná River: composition, community attributes and influence of abiotic factors. Acta Limnologica Brasiliensia, São Carlos, v. 21, n. 4, p. 376-385, 2012. http://dx.doi.org/10.1590/S2179-975X2012005000016

BEZERRA, P. S. S.; TAKIYAMA, L. R.; BEZERRA, C. W. B. Complexação de íons de metais por matéria orgânica dissolvida: modelagem e aplicação em sistemas reais. Acta Amazonica, Manaus, v. 39, n. 3, p. 639-648, 2009. http://dx.doi.org/10.1590/S004459672009000300019

BOYD, C. E.; MASSAUT, L. Risks associated with the use of chemicals in pond aquaculture. Aquacultural Engineering, Essex, v. 20, p.113-132, 1999.

http://dx.doi.org/10.1016/S0144-8609(99)00010-2

BOYD, C. E. Copper use in the aquaculture. The Global Aquaculture Advocate, Saint Louis, v. 18, n.1, p. 38-39, 2015.

CAMARGO, A. F. M.; PEZZATO, M. M.; HENRY-SILVA, G. G. Fatores limitantes a produção primária de macrófitas aquáticas. In: THOMAZ, S. M.; BINI, L. M. Ecologia e manejo de macrófitas aquáticas. Maringá: EDUEM, 2003. p. 59-83.

CARDEILHAC, P. T.; WHITAKER, B. R. Tropical fish medicine. Copper treatments. Uses and precautions. The Veterinary Clinics of North America: Small Animal Practice, Philadelphia, v. 18, n. 2, p. 435-448, 1988.

CARY, P. R.; WEERTS, P. G. J. Growth of Salvinia molesta as affected by water temperature and nutrition. III. Nitrogen-phosphorus interactions and effect of $\mathrm{pH}$. Aquatic Botany, Amsterdam, v. 19, n. 1-2, p. 171-182, 1984. http://dx.doi.org/10.1016/03043770(84)90015-9

CONSELHO NACIONAL DO MEIO AMBIENTE - CONAMA (Brasil). Resolução 430 de 13 de maio de 2011. Disponível em: <http://www.mma.gov.br/port/conama/res/res 11 /propresol_lanceflue_30e31mar11.pdf>. Acesso em: 15 maio 2015.

CRUZ, M. B.; KARAM, D.; AGUIAR, R.; MELLO, J. W. V. Absorção de metais pesados presentes em efluentes de mineração por Pistia stratiotes. In: CONGRESSO DE ECOLOGIA DO BRASIL, 9., 13-17 Set., São Lourenço. Anais... São Lourenço: Sociedade de Ecologia do Brasil, 2009. 
DEMBITSKY, V. M.; REZANKA, T. Natural occurrence of arseno compounds in plants, lichens, fungi, algal species, and microorganisms. Plant Science, Limerick, v. 165, n. 6, p. 1177-1192, 2003. http://dx.doi.org/10.1016/j.plantsci.2003.08.007

ESPINOZA-QUIÑONES, F. R.; ZACARLEIN, C. E.; PALACIO, S. M.; OBREGON, C. L.; ZENATTI, D. C.; GALANTE, R. M. et al. Removal of heavy metals from polluted river using aquatic macrophytes Salvinia sp. Brazilian Journal of Plant Physiology, São Paulo, v. 35, n. 3, p. 744-746, 2005. http://dx.doi.org/10.1590/S010397332005000500005

KUMAR, J. I. N.; H. SONI, R. N. K.; BHATT, I. Macrophytes in phytoremediation of heavy metal contaminated water and sediments in Pariyej Community Reserve, Gujarat, India. Turkish Journal Fisheries and Aquatic Sciences, Trabazon, v. 8, n. 2, p. 193-200, 2008.

LADISLAS, S.; EL-MUFLEH, A.; GERENTE, C.; CHAZARENC, F.; ANDRES, Y.; BECHET, B. Potential of aquatic macrophytes as bioindicators of heavy metal pollution in urban storm water Runoff. Water Air Soil Pollution, Dordrecht, v. 223, n. 2, p. 877888, 2012. http://dx.doi.org/10.1007/s11270-011-0909-3

MANSOURI, B.; EBRAHIMPOUR, M.; POURKHABBAZ, A; BABAEI, H.; FARHANGFAR, H. Bioaccumulation and elimination rate of cobalt by Capoeta fusca under controlled conditions. Journal of Animal \& Plant Sciences, Lahore, v. 22, n. 3, p. 622-626, 2012.

MARENGONI, N. G.; KLOSOWSKI, E. S.; OLIVEIRA, K. P.; CHAMBO, A. P. S.; JUNIOR, A. C. G. Bioacumulação de metais pesados e nutrientes no mexilhão dourado do reservatório da usina hidrelétrica de Itaipu binacional. Química Nova, São Paulo, v. 36, n. 3, p. 359-363, 2013. http://dx.doi.org/10.1590/S0100-40422013000300002

MAZON, A. F.; PINHEIRO, G. H. D.; FERNANDES, M. N. Contaminação dos ecossistemas aquáticos pelo cobre e risco potencial a biodiversidade: estudo da toxicidade do cobre em curimbatá, Prochilodus scrofa (Teleostei, Prochilodontidae). In: ESPÍNDOLA, E. L. G.; PASCHOAL, C. E. R. M.; ROCHA, O.; BOHRER, M. B. C.; OLIVEIRA NETO, A. L. (Orgs). Ecotoxicologia: perspectivas para o século XXI. São Carlos: RIMA, 2000. p. 327-340.

McBRIDE, M.; SAUVE, S.; HENDERSHOT, W. Solubility control of $\mathrm{Cu}, \mathrm{Zn}, \mathrm{Cd}$ and $\mathrm{Pb}$ in contaminated soils. European Journal of Soil Science, Oxford, v. 48, n. 2, p. 337-346, 1997. http://dx.doi.org/10.1111/j.1365-2389.1997.tb00554.x

McFARLAND, D. G.; NELSON, L. S.; GRODOWITZ, M. J.; SMART, R. M.; OWENS, C. S. Salvinia molesta D. S. Mitchell (Giant Salvinia) in the United States: a review of species ecology and approaches to management. Vicksburg: U.S. Army Engineer Research and Development Center, 2004. 33 p.

MEERHOFF, M.; MAZZEO, N.; MOSS, B.; RODRÍGUEZ-GALLEGO, L. The structuring role of free-floating versus submerged plants in a subtropical shallow lake. Aquatic Ecology, Springer Netherlands, v. 37, n. 4, p. 377-391, 2003.

MILAN, B.; SLOBODANKA, P.; ŽIVKO, S.; BORIVOJ, K. Macrophytes as phytoindicators and potential phytoremediators in aquatic ecosystems. In: INTERNATIONAL CONFERENCE: International Austrian Committee Danube Research, 2006, Vienna. Proceedings... [S.1.:s.n], 2006. 
MÓDENES, A. N.; ESPINOZA-QUIÑNONES, F. R.; LAVARDA, F. L.; COLOMBO, A.; LEICHTWEIS, W. A.; MORA, N. D. Remoção dos metais pesados Cd(II), Cu(II) e Zn(II) pelo processo de biossorção utilizando a macrófita Eichhornia crassipes. REM: R. Esc. Minas, Ouro Preto, v. 66, n. 3, p. 355-362, 2013. http://dx.doi.org/10.1590/S0370-44672013000300013

MOKHTAR, H.; MORAD, N.; FIZRI, F. F. A. Phytoaccumulation of copper from aqueous solutions using Eichhornia crassipes and Centella asiatica. International Journal of Environmental Science and Development, Singapore, v. 2, n. 3, p. 205-210, 2011.

MONDARDO, É.; JUNIOR, A. C. G.; SACON, E. Uso da macrófita aquática (Eichhornia crassipes) na remoção de cobre e zinco em biofertilizantes de origem suína. Ciências Exatas e da Terra, Agrárias e Engenharias, Ponta Grossa, v. 12, n. 2, p. 13-20, 2006.

MORMUL, R. P.; THOMAZ, S. M.; HIGUTI, J.; MARTENS, K. Ostracod (Crustacea) colonization of a native and a non-native macrophytes species of Hydrocharitaceae in the Upper Paraná floodplain (Brazil): an experimental evolution. Hydrobiologia, The Hague, v. 644, n. 1, p. 185-193, 2010. http://dx.doi.org/10.1007/s10750-010-0112-3

MOYO, N. A. G.; PHIRI, C. The degradation of urban streams in Harare, Zimbabwe. African

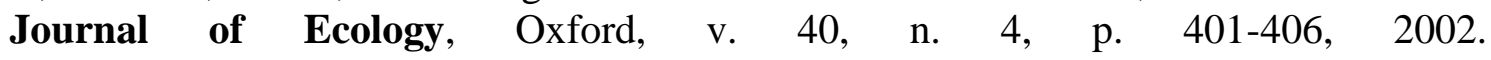
http://dx.doi.org/10.1046/j.1365-2028.2002.00399.x

PENNING, W. E; DUDLEY, B.; MJELDE, M.; HELLSTEN, S.; HANGANU, J.; KOLADA, A. et al. Using aquatic macrophyte community indices to define the ecological status of European lakes. Aquatic Ecology, Springer Netherlands, v. 42, n. 2, p. 253-264, 2008. http://dx.doi.org/10.1007/s10452-008-9183-x

POURAHMAD, J.; O' BRIEN, P. J. A comparision of hepatocyte cytotoxic mechanisms for $\mathrm{Cu}^{2+}$ and $\mathrm{Cd}^{2+}$. Toxicology, Amsterdam, v. 143, n. 3, p. 263-273, 2000. http://dx.doi.org/10.1016/S0300-483X(99)00178-X

PROENÇA, M. A.; OLIVEIRA, L. L. D.; ROCHA, O. Efeito tóxico do cobre sobre o crescimento da macrófita aquática Lemna minor. Fórum Ambiental da Alta Paulista, v. 8, n. 12, p. 196-207, 2012. http://dx.doi.org/10.17271/198008278122012365

RASCIO, N.; NAVARI-IZZO, F. Heavy metal hyperaccumulating plants: How and why do they do it? And what makes them so interesting? Plant Science, Limerick, v. 180, p. 169-181, 2011. http://dx.doi.org/10.1016/j.plantsci.2010.08.016

ROOM, P. M. Falling apart as a lifestyle: the rhizome architecture and population growth of Salvinia molesta. Journal of Ecology, Oxford, v. 71, n. 2, p. 349-365, 1983. http://dx.doi.org/10.2307/2259719

RUBIM, M. A. L.; CAMARGO, A. F. M. Taxa de crescimento específico da macrófita aquática Salvinia molesta Mitchell em um braço do Rio Preto, Itanhaém, São Paulo. Acta Limnologica Brasiliensia, São Carlos, v. 13, n. 1, p. 75-83, 2001.

SNOW, A. M; GHALY, A. E. A comparative study of the purification of aquaculture wastewater using water hyacinth, water lettuce and parrot's feather. American Journal of Applied Sciences, Vails Gate, v. 5, n. 4, p. 440-453, 2008.

SCULTHORPE, C. D. The biology of aquatic vascular plants. London: Edward Arnold, 1967. $610 \mathrm{p}$. 
SÚAREZ, Y. R.; FERREIRA, F. S; TONDATO, K. K. Assemblage of fish species associated with aquatic macrophytes in Porto Murtinho Pantanal, Mato Grosso do Sul, Brazil. Biota Neotropica, Campinas, v. 13, n. 2, p. 182-189, 2013. http://dx.doi.org/10.1590/S1676-06032013000200017

SUÑE, N.; SÁNCHEZ, G.; CAFFARATTI, S.; MAINE, M. A. Cadmium and chromium removal kinetics from solution by two aquatic macrophytes. Environmental Pollution, Barking, v. 145, p. 467-473, 2007. http://dx.doi.org/10.1016/j.envpol.2006.04.016

THOMAZ, S. M.; CUNHA, E. R. The role of macrophytes in habitat structuring in aquatic ecosystems: methods of measurement, causes and consequences on animal assemblages composition and biodiversity. Acta Limnologica Brasiliensia, São Carlos, v. 22, n. 2 , p. 218-136, 2010. http://dx.doi.org/10.4322/actalb.02202011

TUNDISI, J. G.; TUNDISI, T. M. Limnologia. São Paulo: Oficina de Textos, 2008. 631 p.

UGYA, A. Y.; IMAM, T. S.; TAHIR, S. M. The Use of Pistia stratiotes to remove some heavy metals from Romi Stream: a case study of Kaduna Refinery and Petrochemical Company Polluted Stream. Journal of Environmental Science, Toxicology and Food Technology, Ghaziabad, v. 9, n. 1, 48-51, 2015. http://dx.doi.org/10.9790/240209124851

WETZEL, R. G.; LIKENS, G. Limnological analyses. New York: Springer Verlag, 1991. $391 \mathrm{p}$.

WORLD HEALTH ORGANIZATION. Cooper. Enviromental Health Criteria 200. Geneva, 1998.

WOLFF, G.; ASSIS, L. R.; PEREIRA, G. C.; CARVALHO, J. G.; CASTRO, E. M. Efeito da toxicidade do zinco em folhas de Salvinia auriculata cultivadas em solução nutritiva. Planta Daninha, Viçosa, v. 27, n. 1, p.133-137, 2009. http://dx.doi.org/10.1590/S010083582009000100017 